\title{
Metaphoric Associative Cards - Tool for Career Counselling with Long-Term Unemployed
}

\author{
(D)Anna Bickovska Mg. ed. \\ Latvia University of Life Sciences and Technologies, Latvia \\ annabickovska@inbox.lv
}

\begin{abstract}
Topicality of the research is that a significant part of unemployed stay unemployed for a very long time even when the economic situation allows to get employed. This part of society abuses the social security system, misuse the State Employment Agency services. Typically, they are seen by society as less educated, less capable than other groups and they need special assistance in job searching process. The aim of the pilot study was to explore how more creative and skill-oriented methods can be used in career counselling with long-term unemployed. The methodology includes following steps: small group of long-term unemployed (8 women) were asked to reflect on their unemployment and answer 4 questions developed by the author. Questions are covering their opinions on reasons of being unemployed, what kind of a result they want to achieve, what resources they can use and how they are going to feel in case they become employed. Results shows that most participants of the group consider that they can't find a job because of external obstacles. They mention the State Employment Agency and relatives (families) as resources to use. All respondents were confused answering question about their feelings and cannot name any feeling they might feel getting a job. The results and process of the session show that long-term unemployed have difficulties with soft skills and emotional intelligence.
\end{abstract}

Keywords: career counselling, long-term unemployed, metaphoric associative cards.

\section{Introduction}

The aim of the study is to represent a more creative tool for career counselling with the long-term unemployed. State Employment Agency provides many different services for unemployment to help them return to the labour market getting additional education, training and certification. The long-term unemployed are able-bodied persons who have been registered at State Employment Agency more than one year (Support for Unemployed..., 2002). Before pandemic the level of unemployment was not that high in Latvia (vary in different regions, but the total country wise in February 2020 was $6.3 \%$ ) and now, in October it is 7.4 \% (Pārskats par bezdarba..., 2020) and $22 \%$ or 15500 people are long-term unemployed.

Long-term unemployment has significant impact not only on economic, but also on personal level. Long-term unemployment can have serious adverse effects for individuals as it entails the depreciation of skills, the more difficult is to get hired, less time devoted to the job search and hence more probabilities of leaving the labour market. Consequently, a high level of long-term unemployment threatens social cohesion as it exposes individuals to a risk of social exclusion and society to high levels of structural unemployment (Blázquez, Herrarte, Sáez, 2018). There might be different reasons why people stay unemployed when it is possible to get a job - health issues, language issues or addictions. According to F.K. Lee and J.A. Johnston unemployment has a significant impact on psychological health issues, individual wellbeing, self-efficacy, and self-esteem (Lee, Johnston, 2001).

Denmark experience shows that long-term unemployed participance in mandatory activation programmed increases participants chance to get employed for $30 \%$ (Graversen, van Ours, 2008). That means that any type of activities long-term unemployed is taking part in may bring positive changes and raise opportunity to get job.

Reflecting on author' personal, almost 10 years long, experience in different types of work with long-term unemployed the variety of services that long-term unemployed is able to get is focused on very technical and practical skills - education, cover letter writing, preparing CV and language training. All those skills are topical in regard to job hunting, finding and holding.

According to J. Laskova and L. Brokane study best way to introduce job searching opportunities for long-term unemployed is during individual consultation, because it allows to evaluate individual experience and needs (Laskova, Brokane, 2014) and it is why such method as dialogue is so important 
and widely use working with any type of unemployed and long-term as well. This space of dialogue develops through major inflection points or crises because it is able to maintain individual's experience in increasingly rich and more complexity ways, making it lawful through many approaches and styles (Soika, 2017). Individual work with long-term unemployed, dialogue-based sessions can bring significant results to individuals' lives. During sessions with career counsellor different topics can be discussed and individual can be softly pushed to reflect about the current situation, emotions and feelings that it brings up in conversation. Unfortunately, not all long-term unemployed can receive full-time individual sessions and not all of them are truly interested in that type of assistance. That's why work in small groups still can bring significant differences when there is an opportunity to express thoughts, to have dialogue with group moderator and other participants.

For being successfully employed it is important not only to obtain degree, toe get certificate or any other legal prove that individual is allowed to work in a certain field. Educations gives more than just formal part of it. Because education has three aspects: 1) it is related to knowledge of the external world, i.e., it is the accumulation of secular and scientific information; 2) transformation of a human being, i.e., development of the character; 3 ) learning of the human being himself, and the best object to learn about the Human Being (Baltusite, Katane, 2017). It gives idea that not only formal part of job searching (like education, CV and cover letter, interview) is important, but also emotional and inner part of life that bring topic of importance of soft skills.

Soft skills include such competencies as critical thinking, social aptitudes, communication capability and ability to take part par in teamwork (Cimatti, 2016; Tulgan, 2015). Both - education system and employees consider that soft skills are vital for personal life, professional career and organisational success (Keng Ng, 2020).

One of the crucial components integrating soft skills development to job searching and holding process is practice (Bedwell, Fiore, Salas, 2014), during which long-term unemployed can try to convert knowledge into behaviour.

The author considers that a person who is unemployed for over a year, who experiences deprivation of time structure, who might be procrastinated too much could find more challenging keeping a relationship with colleagues more than with work's technical part. Soft skills include certain abilities such as communication, problem-solving, self-motivation, decision-making, and time management skills (Gupta, 2010).

For long-term unemployed it might be especially hard - they have strictly limited opportunities to communicate with people, to develop different soft skills that can be sharpened only in cooperation and communication with other human beings.

It is important to work on soft skill development and practice using existing ones. There might be different ways how to achieve it - participating in group sessions; receiving individuals' sessions with a coach, career counsellor or psychologist; individual work with available resources - books, audio and video content (might be harder for long-term unemployed, since the level of motivation might be lower than expected to be). Different tools can be used for that work and one of the are metaphoric associative cards (MAC). Such a tool might be great for developing emotional intelligence and reflecting skills for better understating of their own personality and their opportunities and restrictions they might have in their own mind.

MAC - is a modern tool that might be used in different types of therapeutic, consultative, and pedagogical work. It is also a great way to explore your own personality, push your creativity and entertain yourself.

Metaphoric cards were introduced and first published in 1982 by E. Raman, he explored a different use of two-deck interactivity with a pair of decks called Persona, one of portraits, the other of abstract designs that can symbolize possible social interactions or personal relationships. MAC are based on principles of gestalt-therapy, humanistic psychology, C.G. Jung archetypes and J. Campbell myths (Raman, 1995; Jung, 1991; Campbell, Moyers, 1991; Gatineau, 2010).

There are different visual types of MAC decks - organised by colours, topics, ideas, words. The main idea is that all cards in deck relate to something similar and many different scenarios can be played with them. MAC is a widespread type of projective techniques that can quickly and clearly get information 
about the person, his inner state and experience, identify issues that need to be addressed, and see the correlation of internal associative images with external life realities (Hrinchenko, 2018).

Metaphoric cards open a window to a person's inner world; associative reactions to the illustrated cards make it possible to reflect upon childhood memories, to recall repressed experiences, and to release blocked feelings. Since the interpretations of metaphors featured in the cards are completely in the eyes of the beholder, the same card can trigger different reactions in different participants (Ayalon, 2007).

Using MAC might seem like a game, however one of co-operation and sharing rather than competition and achievement. It is essential that "playing the game" gives freedom to players. There is no right or wrong answer or explanation of cards. Using of MAC gives an excellent feeling of ownership to longterm unemployed - they are ruling the cards, they are giving them life and telling the story, allowing them to find their own course (Atkinson, Wells, 2000).

Career counselling does not include therapeutical work with any kind of trauma, but this tool is great for "mouth opening" tasks that push long-term unemployed to verbalise feelings and anxieties. It looks easy and playful to join a session where the main task is to choose colourful cards and speak about them, so during the invitation process long-term unemployed are interested, because they have never participated in any kind of similar activities.

The aim of the study was to explore how MAC as a more creative and skill-oriented method can be used in career counselling with long-term unemployed.

\section{Methodology}

The aim of the author was to try a new method when working with long-term unemployed - get their feedback and use in the future work, to figure out how long-term unemployed can express their feelings and emotions that represent their situation using metaphors itself and MAC as tool.

A survey developed by the author consists of 4 questions which represent respondents' attitude toward themselves, their opportunities and reasons to get employed or staying unemployed and what kind of resources are available to them. The participants were asked to answer these questions before taking part in sessions with MAC and after it. They were also asked to specify their gender, age, period of unemployment and level of education.

Respondents were asked to answer the following questions:

1. What stops you from getting employed?

2. What kind of results do you want to achieve?

3. What resources can you use to get employed?

4. How you are going to feel when you will get employed?

The current empirical research was carried out in one of Riga Social Service departments. 8 long-term unemployed took part in this pilot research. The participants of research were the following: 8 females between the age of 27 to 58 (Mean $(M)=43.625$, Standard Deviation $(\mathrm{SD})=9.7$ ).

\section{Results and Discussion}

Being unemployed for many years in a row brings significant changes to personality itself and cannot be changed or treated during one session with any kind of professional. In Latvian context long-term unemployed have no possibilities to get full access to any kind of treatment they might need - there is no complex approach for that target group. In State Employment Agency they can receive career counsellor sessions and get on the waiting list for additional education. In Social Service they might get assistance of social worker, however since "unemployment" itself, in terms of social service, is not considered as a social problem. Being a social service client, they can get free access to 10 sessions with psychologist, however they need to prove that they have a reason to ask for it.

Not many long-term unemployed are seeking for that type of help, however even if they do - they might get some pieces of a full picture. On the first day of the research all participants were invited to social service and asked to fill in a questionnaire, they were explained why they need to fill it and what will 
happen next. After filling it all of them participated in a session using MAC. They were invited over the next day and asked to fill a questionnaire again.

Experimental career counselling session using A. Grashchenkova deck (Grashchenkova, 2020) is based on SCORE-model. The model was introduced by R. Dilts and T. Epstein in 1987 and includes basics of neuro-linguistic programming (Dilts, Epstein, 1989). A participant takes a piece of paper and write down SCORE (alternatives in their mother tongue), where $\mathrm{S}$ means symptoms, $\mathrm{C}$ - causes, $\mathrm{O}$ - outcomes, $\mathrm{R}$ - resources, $\mathrm{E}$ - effects. Then takes five cards (without choosing the face of cards) and opens it one by one answering questions connected to each card.

The following questions are asked: symptoms - what is the problem? What you want to change? Outcomes - what will you consider as a result? What do you want to achieve as results? What do you want to get instead of you have now? Effects - what will happen after the goal is achieved? How will it affect you? How will it affect your surroundings? Reasons - why are you not in the situation you want to be? What disturbs you? Resources - what do you need to achieve goal? What or who can help you? What steps do you need to take to achieve it?

All questions and reflections going on during the session brings a person to a "problem space". While answering all questions participants make notes that they can bring to themselves. All pilot research participants are Riga Social Service clients - some of them receive social benefits for years, some of them just started using social security system. All of them have secondary education (it includes 5 persons with general secondary education and 3 persons with professional secondary education). Unemployment periods vary starting from 20 months to 51 months.

According to Table 1, answering the first question (before MAC session) "What stops you from getting employed?" (participants could name few reasons) - 7 respondents mentioned that they can't find a job. That can not be true, because the labour market, at this period, offers a variety of positions for people with secondary education. After and while respondents were filling the questionnaire, they mentioned that "they [employers] don't want to choose me". Options like "Language difficulties", "Health issues", "Age issues" and "No resources to leave children with" were mentioned by 2 persons each. One person mentioned option "Not high enough salary offered". When participants answered the question after taking part in session one new answer appeared and 2 persons mentioned that they "Do not want to be employed".

Table 1

\section{Question \#1 "What stops you from getting employed?"}

(respondent can mention few reasons)

\begin{tabular}{|l|c|c|}
\hline Reason (as mentioned by the respondent) & $\begin{array}{c}\text { N, respondents } \\
\text { BEFORE }\end{array}$ & $\begin{array}{c}\text { N, respondents } \\
\text { AFTER }\end{array}$ \\
\hline Can not find a job & 7 & 6 \\
\hline Language difficulties & 2 & 2 \\
\hline Not high enough salary offered & 1 & 1 \\
\hline Health issues & 2 & 2 \\
\hline Age issues & 2 & 2 \\
\hline No resources to leave children with & 2 & 2 \\
\hline
\end{tabular}

Answering the second question before taking part in session all respondents answered that they want to get employed. After the session two persons mentioned that they do not know what result they want to achieve, however six persons answered the same - want to get employed.

While answering a third question "What resources can you use to get employed?" 6 of 8 participants asked researcher (researcher presented during answering questions) what does it mean. They were explained that resources mean - people, they can ask help, institutions and special tools. Seven respondents mentioned that they can use State Employment Agency as resource, three persons mentioned family members, relatives and friends. No one of the respondents has mentioned Social Service or any type of online possibilities as potential help in their job searching.

Answering the last question "How you are going to feel when you will get employed?" all respondents answered that they do not know how they are going to feel. 
To sum up, long-term unemployed have significant problems with expressing their feelings and training their soft skills and emotional intelligence. All tasks of the session included taking card and expressing feelings and emotions, describing situations that look familiar and comes to their mind. That's proven by respondents replying to the last question of the survey - how they are going to feel after getting a job, no one was able to answer and describe it. The field of soft skills might be hard not only for long-term unemployed, but also for university graduates (Widiyono, 2019). Soft-skills training should be implemented in training programs for long-term unemployed.

Important aspect of willing to get employed is motivation. According to H. Gudjons motivation is one of the crucial preconditions for learning (Gudjons, 1998). All respondents are clients of State Employment Agency and Social Service for many years, however still have not solved their problems (at least what to society seems like problem). Therefore, it means that individuals do not have any inner motivation to use their new skills, knowledge and support for job searching and continue to remain unemployed.

Motivation is the hardest aspect to change and to influence for professionals, there is not a big opportunity for long-term unemployed to change their lifestyle and get back to labour market, to change their social life and improve relationships. It is widely known, struggle in a job context impacts not only the job itself - it brings complications to relationships with family, with themselves; brings severe changes to personality itself. Few theories explain motivation phenomenon and how to affect it, most of them are highly cognitive, so it can be very frustrating (Krumboltz, Levin, 2010) to use them in work with long-term unemployed since they are mostly acting according to behavioural theories. That statement is proven by the results of the research - long-term unemployed are focused on very practical, behavioural aspects of their lives. They are not reflecting enough on why they are unemployed or what they need to change. The lack of inner motivation, small, but regular financial assistance from social security system, short-term illegal job options cover basic needs and stops them from moving forward.

\section{Conclusions}

In the situation when the average unemployment rate is relatively low and it is possible to get employed several groups of people remain unemployed for years. It means that they manage to deal with that situation financially and emotionally. For them it is easier to cope with it and stay in a "victim's" role in the eyes of society rather than take control over their lives and move forward.

- As a main reason for their unemployment respondents consider inability to find job. Market for the moment is full of open positions, however they still find reasons why they cannot find a job.

- At the same time all of them want to get a job that sounds like inadequate assessment of the situation. It looks like it is obligatory to find a job for long-term unemployed no matter what the obstacles are.

- As resources long-term unemployed consider State Employment Agency, family, relatives and friends. No one mentioned career counsellor as any type of special resource they might use.

- Long-term unemployed are not aware of their feelings and find it difficult to describe them. They cannot even imagine how they are going to feel when they become employed. Probably, because they are not thinking about it as a real opportunity.

- Soft-skill training might be very useful for long-term unemployed. It won't bring fast results (they won't get a job because of it), however it might help them understand themselves, their wishes, skills and opportunities.

- Different sessions and groups where long-term unemployed can take part are oriented to reflecting, what might bring them in a state of cognitive dissonance, what can be a start for them to overthink their future.

- Long-term unemployed receive different support in technical fields - how to create a CV and motivational letter. They can take part in different education activities, however hardly anyone is interested in how they are doing, what they are thinking. Activities that are taking care of their emotional balance and mental wellbeing should be introduced for long-term unemployed in resource programmes.

- Metaphorical associative cards are a suitable creative tool for career counselling with the long-term unemployed. 


\section{Bibliography}

1. Atkinson K., Wells C. (2000). Creative Therapies. A Psychodynamic Approach within Occupational Therapy. Cheltenham: Nelson Thornes Ltd.

2. Ayalon O. (2007). Beyond Words - Trauma-Healing Experience \& Methods in the Wake of the Tsunami Disaster. In O. Ayalon, M. Lahad, A. Cohen (Eds.), Community Stress Prevention, 6. Kiryat Shmona, Israel: Tel Hai Academic College, 31-39. Retrieved from: https://www.icspc.org/wpcontent/uploads/articles/Community-Stress-Prevention-Volume-6.pdf\#page=31

3. Baltusite R., Katane I. (2017). The Modern Teacher's Career. In V. Dislere (Ed.), The Proceedings of the International Scientific Conference Rural Environment. Education. Personality (REEP), 10. Jelgava: LLU, 30-39. Retrieved from https://lufb.llu.lv/conference/REEP/2017/Latvia-UnivAgricult-REEP-2017_proceedings-30-39.pdf

4. Bedwell W.L., Fiore S.M., Salas E. (2014). Developing the future workforce: An approach for integrating interpersonal skills into the MBA classroom. The Academy of Management Learning and Education, 13(2), 171-186. doi: 10.5465/amle.2011.0138

5. Blázquez M., Herrarte A., Sáez F. (2018). Training and job search assistance programmes in Spain: The case of long-term unemployed. Journal of Policy Modelling, 41(2), 316-335. doi: 10.1016/j.jpolmod.2019.03.004

6. Campbell J., Moyers B. (1991). The Power of Myth. New York: Anchor.

7. Cimatti B. (2016). Definition, development, assessment of soft skills and their role for the quality of organisations and enterprises. International Journal for Quality Research, 10(1), 97-130. doi: 10.18421/IJQR10.01-05

8. Dilts R., Epstein T. (1989). NLP in Training Groups. Scotts Valley, CA, NLP University Press.

9. Gatineau C. (2010). OH: "L'aventure interieure" avec les jeux de cartes associatives [OH: "The inner adventure" with associative card games]. Synodies, 40-43 (in French)

10. Grashchenkova A. (2020). Istochnik sily. Mnogoobrazie resursov. Metaforicheskie karty [Source of power. Diversity of resources. Metaphorical cards]. Sankt-Peterburg: Izdatel'stvo Rech' (in Russian)

11. Graversen B.K., van Ours J.C. (2008). How to Help Unemployed Find Jobs Quickly: Experimental Evidence from A Mandatory Activation Program. Journal of Public Economics, 92(10-11), 2020-2035. doi: 10.1016/j.jpubeco.2008.04.013

12. Gudjons H. (1998). Pedagoğijas pamatatzinas [Pedagogical foundations]. Rīga: Zvaigzne ABC. (in Latvian)

13. Gupta Y. (2010). Building a Better Business Student. BizEd, 9(6), 62-63. Retrieved from https://bized.aacsb.edu/-/media/bized2017/full-issue/2010/novdec-2010---no-ads---lowres.ashx\#page $=50$

14. Hrinchenko O.N. (2018). The use of the coaching collection of metaphorical associative cards «Supervision» as one of the possible instruments of professional supply of psychologists. In Collection of research papers Problems of Modern Psychology, 40. Kamianets-Podilskyi, Ukraine: KamianetsPodilskyi National Ivan Ohiienko University and G.S. Kostiuk Institute of Psychology of the National Academy of Educational Sciences of Ukraine, 95-104. doi: 10.32626/2227-6246.2018-40.95-104 (in English, abstract in Ukraine)

15. Jung C.G. (1991). The Archetypes and the Collective Unconscious (Collected Works of C.G. Jung). ( $2^{\text {nd }}$ ed.). UK: Routledge.

16. Keng Ng L. (2020). The Perceived Importance of Soft (Service) Skills in Nursing Care: A Research Study. Nurse Education Today, 85. doi: 10.1016/j.nedt.2019.104302

17. Krumboltz J.D., Levin A.S. (2010). Luck Is No Accident: Making the Most of Happenstance in Your Life and Career. ( $2^{\text {nd }}$ ed.). Atascadero, CA: Impact Publishers.

18. Laskova J., Brokane L. (2014). Opportunities and Motivation for Training Unemployed in Latvia. Procedia - Social and Behavioral Sciences, 116, 649-655. doi: 10.1016/j.sbspro.2014.01.273

19. Lee F.K., Johnston J.A. (2001). Innovations in Career Counselling. Journal of Career Development, 27(3), 177-185. doi: 10.1177/089484530102700304

20. Pārskats par bezdarba situāciju valstī (septembris) [An overview of the unemployment situation in the country (September)]. (2020). Nodarbinātības valsts aǵentūra. Retrieved from https://www.nva.gov.lv/sites/nva/files/content/27\%2010\%2020/parskats-par-bezdarbasituaciju_septembris_2020.pdf (in Latvian) 
21. Raman E. (1995). Persona Cards. Canada: Modern Bu-Jutsu Inc.

22. Soika I. (2017). Evolution of Dialogue for Students' Career Guidance in Secondary Vocational Education. In V. Dislere (Ed.), The Proceedings of the International Scientific Conference Rural Environment. Education. Personality (REEP), 10. Jelgava: LLU, 481-488. Retrieved from https://llufb.llu.1v/conference/REEP/2017/Latvia-Univ-Agricult-REEP-2017_proceedings-481-488.pdf

23. Support for Unemployed Persons and Persons Seeking Employment Law. (2002). Saeima. Retrieved from https://likumi.lv/ta/en/en/id/62539

24. Tulgan B. (2015). Bridging the Soft Skills Gap: How to Teach the Missing Basics to Today's Young Talent. New Jersey: Wiley.

25. Widiyono SE.MM. (2019). The Role of Soft Skills in Preventing Educated Unemployment: A Phenomenological Approach of University Graduates in Jakarta. International Journal of Humanities and Social Science, 5, 202-210. doi: 10.30845/ijhss.v9n5p25 